\title{
1818. La proclamación de la Independencia de Chile: historia y memoria, realidad y mito
}

Jorge Orellana Billiard ${ }^{1}$

Universidad Diego Portales, Chile

jorgeorellana150@gmail.com

Cristián Guerrero Lira y Ulises Cárcamo Sirguiado, 1818. La proclamación de la Independencia de Chile: historia y memoria, realidad y mito, Santiago, Chile, Ediciones Historia Chilena, 2018, 281 pp.

Cristián Guerrero Lira y Ulises Cárcamo Sirguiado, historiadores chilenos, profesores del Departamento de Historia de la Universidad de Chile, analizan en esta obra los principales lineamientos sobre la independencia de Chile para comprender las realidades y mitos que se han sembrado en torno al tema. Asimismo, el libro surge porque en el año 2018 se conmemoró el Bicentenario de la Independencia de Chile y faltaba un texto que volviera a reflexionar sobre la independencia chilena, que actualizara temas como los actos declaratorios, las batallas independentistas y la discusión historiográfica que se ha realizado en torno a la independencia nacional.

El libro coordinado por Guerrero y Sirguiado, 1818. La proclamación de la Independencia de Chile: historia y memoria, realidad y mito, es en este sentido una novedad que se agradece, sobre todo si consideramos que, a diferencia de lo que se ha publicado en los últimos años sobre el tema, este trabajo no se concentra en analizar la Independencia chilena, sus causas,

\footnotetext{
${ }^{1}$ Candidato a Magíster en Historia de América Latina por la Universidad Diego Portales, Santiago de Chile.
} 
los actores y los efectos que produjo sino que busca escribir en torno al Bicentenario de la Proclamación y Jura de la Independencia, respondiendo a la siguiente interrogante ¿ ¿se declaró, proclamó o juró la independencia ¿En Concepción o Talcahuano? (p. 15). Estas ideas son recogidas por los ocho capítulos que conforman la obra: en el primero titulado "El sentido de una historia en construcción” se analizan los conceptos Historia y Memoria Histórica con el fin de precisar sus diferencias y que esto pueda ser comprendido a cabalidad por el lector, para los autores "la Memoria Histórica es reciente y alude al esfuerzo que realizan los diferentes grupos por desentrañar su pasado, en cambio, la Historia no se basa en las memorias subjetivas, sino en la investigación rigurosa de los datos documentados que sobrevivieron del pasado" (p. 35). Por lo tanto, esos dos conceptos también pueden comprenderse a través de ejemplos, los monumentos y un día en el calendario especial permiten conservar la memoria histórica con el propósito de entregar una identidad a la nación; a continuación, el segundo capítulo "Después de Chacabuco" los autores estudian las luchas independentistas en Chile contra los ejércitos del rey, los procesos políticos durante 1818, la creación del Estado como órgano independiente de la monarquía española, los símbolos independentistas el estandarte real, las banderas de las distintas unidades militares, conocidas como coronelas y sus significados, ilustrados en imágenes para comprender el diseño original de estas durante el siglo diecinueve; en el tercer capítulo "Los términos y sus significados" Cristián Guerrero y Ulises Cárcamo revisan el significado del concepto independencia, proclamación, Nación y nacionalidad, patria y ciudadanía durante los siglos XVIII e inicios del XIX; el cuarto capítulo "El Acta de Declaración de Independencia" se analiza el significado del Acto Declaratorio de Independencia no solo en Chile sino en otras naciones a inicios de 1818, además de estudiar los motivos por los cuales Bernardo O’ Higgins firmó en 1818 el acta de la declaración; el quinto capítulo "El Manifiesto y las juras de la Independencia” revisa el manifiesto y las 
ceremonias de la independencia en 1818; luego, el sexto capítulo "12 de Febrero. La tesis tradicional” los autores revisan varias obras historiográficas acerca de la independencia para demostrar como los investigadores e historiadores han expuesto sus tesis sobre la independencia chilena; el séptimo capítulo " 1 de Enero. La tesis penquista” se busca revisar, analizar y criticar a los historiadores penquistas sobre su tesis de que fue en Concepción donde se firmó el acta de declaración de independencia, en tanto, cierra este capítulo titulado “Independencia y nueva patria: Nacionalización en Chile: 1811 - 1823”. Donde se estudia y explica en cómo se conformó la sociedad chilena, qué significaba la ciudadanía y la nacionalidad durante 1817.

En este contexto, nos parece que 1818. La proclamación de la Independencia contiene tres puntos generales que resumen sus principales ideas. El primer tema tiene relación con reafirmar la tesis de que el 12 de febrero de 1817 Chile era independiente, existía una República, normas, símbolos patrios propios que permitían crear este Estado libre. El segundo punto es el resolver el problema de los verbos que emplearon los revolucionarios para referirse al acto de declaración, respondiendo a la interrogante ¿se declaró la independencia de qué? Los autores buscan explicar estas expresiones para evitar la confusión intelectual en los lectores. Finalmente, el tercer punto es referirse a la tesis penquista ¿dónde y cuándo se proclamó o declaró la independencia? Los historiadores se disculpan ante el lector por la extensión de la discusión sobre este tema pero su objetivo es dejar aclarado tal controversia.

El manejo y variedad de las fuentes son relevantes y novedosas. Los autores recurrieron al Boletín de la Cámara de Senadores, el Archivo de don Bernardo O’ Higgins, el Archivo Histórico del Perú, entre otros. Esto es algo de destacar porque permite diferenciarlos de aquellos historiadores que han escrito sobre la independencia de Chile (Simón Collier, Ideas 
y políticas de la independencia de Chile, Alfredo Jocelyn Holt, Independencia de Chile. Tradición, modernización y mito, Sergio Villalobos. Chile 1810 y han revisado las mismas fuentes conocidas los periódicos independentistas (La Aurora de Chile, El Semanario Republicano, El Monitor Araucano, entre otros).

Por último, la capacidad de análisis. Los autores elaboran interesantes conjeturas a partir de temas como la economía en 1818, los conceptos relacionados con Nación, Nacionalidad, Patria y Ciudadanía y la formación del Ejército independentista.

Existen igualmente otros antecedentes que resultan del todo novedosos relativos al Ejército independentista, el abandono de armas y municiones, el saqueo de los caudales reales hechos por los mismos soldados y el ataque hecho a la misma población de Valparaíso en Chile.

Entre estos antecedentes destaca el destino final de las naves de Talcahuano, los tripulantes masculinos y femeninos que iban a bordo, la carencia de suministros para mantener a los pasajeros, motivo que los obligó a desembarcar en el Callao, abastecerse de lo que necesitaban y continuar hacia Talcahuano.

En definitiva, podemos asegurar que el texto de Cristián Guerrero Lira y Ulises Cárcamo Sirguiado es un nuevo impulso para los historiadores de la independencia chilena y americana, y será una referencia obligada para quienes investigan este periodo, por los innumerables datos que aporta desde el punto de vista, histórico, político y militar. 